\title{
Gothic Returns: The Hound of the Baskervilles
}

\section{Janice M. Allan}

As early as November 1891, Doyle wrote to his beloved Ma'am to inform her that he was thinking 'of slaying Holmes ... \& winding him up for good \& all', complaining that the work 'takes my mind from better things'. ${ }^{1}$ While Mary Doyle's horrified response earned the detective a temporary reprieve, 'The Final Problem' saw Holmes, locked in the arms of Moriarty, plunge into the Reichenbach Falls. As Doyle confirmed to his mother, the intention was for Holmes 'never never to reappear' - 'I am weary of his name'. ${ }^{2}$ For almost ten years, Doyle stayed true to his word and it was only in October 1903, with the publication of 'The Empty House' that Doyle gave way to public pressure and financial temptation and brought his most famous creation back to life. It is, therefore, only appropriate that Doyle described The Hound of the Baskervilles as 'a real Creeper'. ${ }^{3}$ Serialised between August 1901 and April 1902 (prior to Holmes' resurrection) but set in 1889 (pre-dating his death), Holmes is neither dead nor alive and thus occupies the liminal position of a ghost, as spectral as the titular hound. In bringing together the scientific detective and the supernatural beast of ancient legend, The Hound occupies a similarly liminal position, poised between the rational positivism of detective fiction and the uncanny ambiguity of the Gothic.

While these two genres appear, on the face of things, to be antithetical in method and intent, it is now widely recognised that they share a common ancestry, albeit one that was denied by early critics of detective fiction who wished to ground its 'literary status on its association with scientific method and highbrow literature'. ${ }^{4}$ It is important to note, however, that Doyle's novel establishes, and indeed relies upon, a binary between science and superstition - the rational and the irrational - if only to reveal the boundary between them to be as slippery and permeable as the mire itself. This chapter will, therefore, explore the 
interaction of the very different topographies - geographical, psychological and symbolic that dominate Doyle's most famous and successful novel.

\section{At Home in London}

While it is the desolate landscape of Dartmoor that remains etched on the memory of readers, the familiar topography of London - captured in the opening five chapters and final retrospection - plays a crucial role in the novel. Structurally, these chapters represent an attempt, albeit never wholly successful, to circumscribe and delimit the uncanny world associated with the Gothic landscape of the moors. Paradoxically, however, they also help to constitute the very uncanniness they work to contain. For as Freud suggests, the production of the uncanny is very much 'an affair of "reality testing"'; it retains its character only "so long as the setting is one of material reality; [and] where it is given an arbitrary and artificial setting in fiction, it is apt to lose that character'. 5 Thus the uncanny, as Nicholas Royle reminds us, 'is not simply an experience of strangeness or alienation ... it is a peculiar commingling of the familiar and unfamiliar'. ${ }^{6}$ London is, in more ways than one, the 'material' basis of all that follows.

Given Holmes's lengthy absence from the pages of the Strand, his re-introduction is surprisingly low key. '[S]eated at the breakfast table' at 221B Baker Street (669) with Watson by his side, the opening of the novel is, above all, recognisable. So too is the ensuing examination of James Mortimer's walking stick - a familiar demonstration of Holmes's observational and deductive prowess - that re-establishes the relationship between Holmes and Watson. Like the stick itself, the opening is 'solid, and reassuring' (669) and the intervening years melt away before the carefully crafted legibility of the tableau. Legibility is, in fact, the keynote of the London chapters and it is only appropriate that they are punctuated by what might be designated as multiple scenes of reading. In addition to Holmes's study of 
the stick, the list of 'texts' subject to scrutiny include: a Medical Directory, the phrenological reading of Holmes's skull, the 1742 manuscript of the Baskerville curse, the report of Sir Charles's death from the Devon County Chronicle, Sir Charles's footprints imprinted onto the 'gravel page' of the Yew Alley (680), an ordnance map, a warning letter, newspapers, a Hotel Directory, the register from the Northumberland, two telegraphs and, finally, the Official Registry of London cabmen. To drive the point home, the scrutiny of texts features in five of the first fourteen illustrations.

The multiplicity of texts within the opening chapters aligns closely with what Srdjan Smajić calls 'the genre's seeing-is-reading model' where the 'visible world is a text, [and] the detective its astute observer and expert reader'. ${ }^{7}$ According to this paradigm, '[b]odies, dead or alive, are perfectly legible, unambiguous texts, but so are all other objects that enter the detective's field of vision ... For the fictional detective, to see is to read - and to read is instantly to know, and know beyond a shadow of doubt' ${ }^{8}$ Holmes is not, of course, infallible - here, his ‘indiscreet eagerness' leads him to lose Stapleton on Regent Street (691) - and Smajić immediately complicates his model by acknowledging the impact of erroneous inference. What is interesting, however, in the context of the London chapters of the Hound, is the ideal of legibility that they establish. Armed with his extraordinary observational skills, a 'passion for definite and exact knowledge' (STUD 17), as well as a vast array of reference sources, Holmes is, according to Smajić's argument, a master reader and semiotician. In one of the novel's many instances of doubling, discussed below, he appears to collect and pin down meaning in much the same way as Stapleton does butterflies. In so doing, he attempts to bring "'detection as near an exact science as it will ever be brought in this world"' (STUD 33). Such precision and legibility stand in stark contrast to the ambiguity and undecidability that is so closely associated with the Gothic, which is, as Victoria Margree and Bryony Randall suggest, characterised by 'an uncertainty as to what if any epistemological frame can 
make sense of the phenomena with which [it is] dealing'. In fact, this 'undecidability - at once epistemological and political - is key to the unsettling quality of Gothic fin-de-siècle literature' 9

Holmes's reading of the ordnance map of Dartmoor offers an interesting example of these two paradigms coming into contact. Having returned from a day at his club, Watson walks into the sitting-room to see 'a vague vision of Holmes in his dressing-gown coiled up in an armchair with his black clay pip between his lips'. As the detective announces, "II have been to Devonshire"":

'My body has remained in this armchair and has, I regret to observe, consumed in my absence two large pots of coffee and an incredible amount of tobacco. After you left I sent down to Stamford's for the Ordnance map of this portion of the moor, and my spirit has hovered over it all day. I flatter myself that I could find my way about'. (683)

This often cited passage has received a good deal of attention and critics have, quite rightly, stressed the extent to which it challenges the science/superstition binary that structures the novel. On the one hand, it is possible to associate it with what Christopher Pittard, building on the work of Lynda Nead, describes as a 'panoptic view from above, in which all is visible and immediately comprehensible'. ${ }^{10}$ In the words of Nead herself, 'the viewpoint represented in the map and the plan' 'turns the heterogeneous world of the city into a text; it renders complexity legible and comprehensible'. ${ }^{11}$ Thus the scene appears to conform to the 'seeingis-reading' paradigm described above. At the same time, however, there is no doubt that the otherworldly vision of the 'coiled' Holmes - suggesting an animalistic, even reptilian creature - recounting an out-of-body experience, jars with the tenets of positivist rationalism and hints at Doyle's commitment to spiritualism. The 'vague' vision of Holmes also anticipates Watson's first view of the moor, 'dim and vague in the distance' (700). Thus this 
is one of many indications of the extent to which the novel depends upon 'the perception of an essential difference that is then subject to challenge or collapse'. ${ }^{12}$

Key to many readings of this scene is the question of perspective; it is 'the panoptic view from above' that is significant. And yet, this emphasis on the viewer says little about the map itself. Despite being of a very large scale, the map, by its very nature, frames and delimits the space it represents. This delimitation is emphasised, moreover, not only by Holmes confining his attention to the single section depicting " "the particular district which concerns us" (683) but also by focusing solely on its domesticated spaces: a "“few scattered dwellings" rather than the space that " extends"" beyond them (683-4). At the same time, the map reduces the moor's treacherous lows and jagged heights to so many concentric circles, transforming the unquantifiable depths of Grimpen Mire to a perfectly legible surface. In giving the indeterminate space of the moors a definite form, moreover, the map places the investigation on a metaphorically firm footing. In short, the map constructs the district as a contained and quantifiable space: a space that is, to invert the terms of Tyler Roeger's reading of oceanic spaces, discussed below, amenable to 'certainty and conclusion' ${ }^{13}$

Those familiar with the canon may well recognise a certain resemblance between the external topography of Dartmoor, as represented by Holmes's map, and the delimited inner topography of the detective himself. As he explains in A Study in Scarlet: “"a man's brain ... is like a little empty attic"” and it is "“a mistake to think that that little room has elastic walls and can distend to any extent"' (21). Thus only

\footnotetext{
'A fool takes in all the lumber of every sort that he comes across, so that the knowledge which might be useful to him gets crowded out, or at best is jumbled up with a lot of other things, so that he has a difficulty in laying his hands upon it. Now the skilful workman is very careful indeed as to what he takes into his brain-attic. He will have
} 
nothing but the tools which may help him in doing his work, but of these he has a large assortment, and all in the most perfect order'. (21)

The principle of circumscription that provides the foundation for Holmes's 'brain-attic' is all the more important when he is confronted with a mystery that is routinely associated with formlessness and depth - as Holmes admits to Watson, "II am not sure that of all the five hundred cases of capital importance which I have handled there is one which cuts so deep"' (693). Thus it is not surprising that the 'seclusion and solitude' (683) - the thinking space, as it were - that is essential to Holmes's investigative process is here taken to an extreme. Upon his return to Baker Street, Watson opens the window to clear the haze of smoke in which Holmes is enveloped. And yet, immediately after he recounts his spiritual journey to Devonshire, Holmes announces: "“I think we'll shut that window again, if you don't mind. It is a singular thing, but I find that a concentrated atmosphere helps a concentration of thought. I have not pushed it to the length of getting into a box to think, but that is the logical outcome of my convictions"” (684). Situated within this metaphorical comfort zone, Holmes is confident not only in his ability to 'find [his] way about' but also in the belief that the 'thing takes shape ... It becomes coherent' $(683 ; 685)$.

\section{The Footprints of a Gigantic Hound}

Chapter six marks a transition - always allowing for the ongoing slippage - between the novel's two very different physical and symbolic topographies: the legible terrain of modern London and the primitive Gothic landscape of Devon. As my argument, thus far, has concentrated on the former, this is a timely moment to remind ourselves that The Hound of the Baskervilles is saturated with the familiar tropes of the Gothic. Amongst such features are a fragmented narrative (consisting of an ancient manuscript, letters, telegraphs and journal entries), a family curse, questions relating to lineage and inheritance, entrapment (physical 
and metaphorical), a persecuted woman and 'domestic tyrant' (715), doubles, a tell-tale portrait, aberrant and heightened states of mind and an ancient manor, Baskerville Hall, 'a place of shadow and gloom' (703). Travelling towards the Hall, Watson notes how, 'behind the peaceful and sunlit countryside there rose ever, dark against the evening sky, the long, gloomy curve of the moor, broken by the jagged and sinister hills' (700). In much the same way, a sense of unspecified dread looms over all the characters. As Sir Henry enters his ancestral home, 'long shadows trailed down the walls and hung like a black canopy above him' (702). Despite vowing to "'have a row of electric lamps up here inside of six months" (702), shadows predominate, an apt metaphor for how the dark mysteries of the past intrude themselves into a supposedly enlightened present. Such intrusions are also marked in the novel's soundscape. From the first night at Baskerville Hall, when its 'deathly silence' is interrupted by 'the sob of a woman, the muffled, strangling gasp of one who is torn by an uncontrollable sorrow' (704) to the hound's 'last howl of agony' (757), the characters are haunted by the sounds of the moor.

Most memorable of the novel's Gothic features is the legendary hound itself: "'a huge creature, luminous, ghastly, and spectral"" which initiates "“a reign of terror"” in the district (681). The ontological impossibility of a 'spectral hound which leaves material footmarks' (727) - an uncanny blurring of the real and unreal - is a particularly clear example of Gothic undecidability, what Kelly Hurley describes as 'the grey area at the borderline between known and unknown, or extra-rational phenomena'. ${ }^{14}$ Such undecidability is evident when Holmes demands of Mortimer, "'you, a trained man of science, believe it to be supernatural?", and Mortimer responds, "I do not know what to believe"” (681). When Watson and Holmes finally encounter the creature on the moors, it is, even by today's standards, a wonderfully effective (and affective) moment. 
A hound it was, an enormous coal-black hound, but not such a hound as mortal eyes have ever seen. Fire burst from its open mouth, its eyes glowed with a smouldering glare, its muzzle and hackles and dewlap were outlined in flickering flame. Never in the delirious dream of a disordered brain could anything more savage, more appalling, more hellish be conceived than that dark form and savage face which broke upon us out of the wall of fog. (757)

Although the first sight of the creature leaves Holmes, Watson and Lestrade 'paralyzed' with fear, the threat embodied by the hound - a threat both literal and ontological - is neutralised by the entirely material expedient of Holmes's pistol. Once dead, moreover, it becomes clear that there is nothing otherworldly about the creature, which is revealed to be nothing more than a 'gaunt, savage' mongrel. Although it is 'as large as a small lioness', its most disturbing aspects are reduced to mere trickery: a 'cunning preparation' of phosphorus to make the creature appear to glow and burn (757).

In offering a rational explanation for a purportedly supernatural event, Doyle is following the lead of conservative Gothic writers such as Ann Radcliffe (author of The Mysteries of Udopho (1794)) who relied on the so-called 'supernatural explained' as a means to moderate the more radical elements of the genre. And thus, paradoxically, the novel's most obviously Gothic episode is actually deployed in the service of what Catherine Belsey describes as the 'project' of the Holmes canon: 'to dispel magic and mystery, to make everything explicit, accountable, subject to scientific analysis'. ${ }^{15}$ In killing the hound Holmes has not only saved Sir Henry but the concept of legibility itself. In order, therefore, to continue an exploration of the novel's Gothic undecidability, we must turn to the moor. For unlike the meaning of the legendary hound which, at the end of the day, can be pinned down like one of Stapleton's specimens, the moor - as both a geographical and symbolic space proves far more resistant to interpretation. 


\section{Journeys through Space and Time}

As is routinely acknowledged in critical readings of the novel, the journey from London to Dartmoor has a temporal as well as a spatial dimension. In the words of Nils Clausson, it is 'represented as a regressive journey into the primitive'. ${ }^{16}$ It begins on a train - a wellrecognised symbol of modernity - and ends in an old-fashioned wagonette, travelling slowly down 'lanes worn by centuries of wheels' (700). For Sir Henry, who has only just arrived from the 'New World' of Canada, the temporal distance covered is even more striking. Describing 'this most God-forsaken corner of the world' in his first report to Holmes, Watson explains:

When you are once out upon its bosom you have left all traces of modern England behind you, but, on the other hand, you are conscious everywhere of the homes and the work of the prehistoric people ... As you look at their gray stone huts against the scarred hillsides you leave your own age behind you, and if you were to see a skin-clad, hairy man crawl out from the low door, fitting a flint-tipped arrow on to the string of his bow, you would feel that his presence there was more natural than your own. (712)

Home to creatures 'practically extinct' elsewhere (708), that live amongst its '[r]ank reeds and lush, slimy water-plants' (759), the moor is reminiscent of a lost primordial world. Thus it is only appropriate that two of the three characters most closely associated with its primitive and uncivilised landscape - Selden, the ferocious Notting Hill murderer, Jack Stapleton, the murderous descendent of Sir Hugo Baskerville and, at least for Watson, Holmes himself - are atavistic criminal throwbacks. Read through the lens of criminal anthropology, such characters belong to an earlier, more primitive stage in evolutionary history. Selden is depicted not as a fully evolved man but, rather, as belonging to a lower species. He hides 'in a burrow like a wild beast' (701) and is characterised by 'a terrible 
animal face' and the agility of a 'mountain goat' (725). In a series of doublings that trouble class and specieal boundaries, Selden is aligned both with Stapleton (they share an intimate knowledge of the moors and are associated with unusually violent crimes as well as the foreign (Selden plans to escape to South America, the birthplace of Stapleton)) and the titular hound (both are hungry, vicious creatures that haunt the moors by night). Indeed, the description of Selden as 'half animal and half demon' (748) applies equally well to the hound.

In the portrait reading scene that dominates chapter thirteen, Stapleton is revealed to be the direct descendent and double of Sir Hugo, the origin and cause of the Baskerville family curse. Having inherited his ancestor's 'wanton and cruel humour' (674) through a father who is, unlike his two brothers, of "the old masterful Baskerville strain"” (681), he (or Rodger Baskerville to give him his proper name) is "“an interesting instance of a throwback, which appears to be both physical and spiritual"' (750). Although motivated by simple greed - he wishes to eliminate those who stand between him and the family fortune - the strange and ferocious nature of the naturalist's crimes testifies to what Clausson describes as a 'regression down the evolutionary scale to primitivism and savagery'. ${ }^{17}$ Approaching the portrait as might Alphonse Bertillon, the French criminologist and Mortimer's idol, Holmes is able to see past the superficial details of fashion and costume in order to isolate what Bertillon calls the 'the real, actual presence of the person'. ${ }^{18}$ This act of circumscription allows the portrait to become legible, even to Watson, who is shocked to see how the 'face of Stapleton had sprung out of the canvas' (750). Significantly, this moment of recognition reenforces Stapleton's doubling with Selden, who 'sprang to his feet' when confronted by Watson and Sir Henry and, even more telling, the hound itself: 'the dreadful shape which had sprung out upon us from the shadows of the fog' (757). It is, finally, worth noting that the portrait scene, like the map reading episode discussed above, brings together the novel's very 
different paradigms. If the principle of Bertillonian circumscription produces legibility, it quickly melts into Gothic irrationality as Holmes admits that the hereditary resemblance between the two men is " "enough to convert a man to the doctrine of reincarnation"” (750). Once again, the boundaries between science and superstition blur and fade.

\section{Grimpen Mire}

As was recognised by its earliest critics, the Gothic is an affective mode of writing; one that is designed to provoke a physical response in the reader, be that suspense, dread or even terror. And thus Watson has 'tried to make the reader share those dark fears and vague surmises which clouded [their] lives so long' (759). Mortimer's whispered announcement "“they were the footprints of a gigantic hound" - for example, is designed to make the reader 'shudder' alongside Watson himself (679). In The Hound, however, the affective power of the Gothic is complemented by the affective potential of the moor itself; its ability to impact identity already signalled by the proliferation of doubles discussed above. Thus the novel lends itself well to a psychogeographical reading. As suggested by French Marxist critic Guy Debord, psychogeography is the 'study of the specific effects of the geographical environment, consciously organised or not, on the emotions and behaviour of individuals'. ${ }^{19}$ As we shall see, the geographical environment of the moors affects not only its inhabitants but, more profoundly, the epistemological framework that they bring to bear upon its mysteries.

From the moment that Watson arrives in Devonshire, he appears to become increasingly liable to the influence of his surroundings. On the first night, sat with Sir Henry in a 'little circle of light', he notes that 'one's voice became hushed and one's spirit subdued' (703). As Watson admits the following morning, their circumstances 'tinged my thoughts with sadness' and he confesses to being “"conscious of shadows all around me"” while his 
'soul' is full of 'vague fears' (712). As if infected by the inchoate nature of his primeval surroundings, the boundaries between subject and environment break down, allowing 'the spirit of the moor [to] sink into one's soul' (712). Under its influence, Watson appears to suffer an existential crisis in which life "'has become like that great Grimpen Mire, with little green patches everywhere into which one may sink and with no guide to point the track", (711). As inner and outer topographies align, Watson's thoughts become as 'dim and vague' (714) as the outlines of the moor itself.

It is only appropriate that the term 'vague' is employed here and elsewhere to describe Watson's internal and external landscape, for this space is - in stark contrast to the circumscribed and legible topography associated with both London and Holmes's own 'brain-attic' - formless and indefinite. Like 'some fantastic landscape in a dream', it is the repository of "“wonderful secrets"” (700; 707). Its sheer size - Watson describes it as "“vast, and so barren, and so mysterious"' (707) - challenges the 'seeing-is-reading' paradigm described above. Where the circumscribed and legible surface produced by the ordnance map instils false confidence in Holmes - "II flatter myself that I could find my way about" (683) - the reality is markedly different. As Stapleton informs Watson, a "'false step yonder means death to man or beast" and neither will "know the difference until the mire has them in its clutches"” (707, 708). Believing that he has discovered the reason behind Stapleton's aversion to Sir Henry as a suitor to his sister, Watson claims that it is 'something to have touched bottom anywhere in this bog in which we are floundering' (720). But given that Stapleton's explanation is a lie, designed to hide the true nature of the siblings' relationship, the 'bottom' falls away and, with no firm foundation upon which to interpret events, the 'moor with its mysteries and its strange inhabitants remains as inscrutable as ever' (726).

In a recent exploration of the role of oceanic space in antebellum detective and Gothic fiction, Roeger argues that the ocean's porousness provided 'a counter imaginary' to the 
'geometric stability' of urban space. ${ }^{20}$ 'This juxtaposition', he asserts, 'emphasizes the uneasy footing the sea creates for those trying to piece the clues together as they reach for a stable surface that does not seem to exist'.${ }^{21}$ Despite the obvious differences between oceanic space and that of the moor, both 'swallow meaning below the surface' and thus are 'hostile to certainty and conclusion'. ${ }^{22}$ It is, therefore, hardly surprising that Watson feels as though a 'dead wall ... [was] built across every path by which I tried to get at the object of my mission' (735). Nowhere, however, is the epistemological threat posed by the moor more obvious than in the thick fog that envelops Grimpen Mire on the night of the hound's attack on Sir Henry. Likened to a 'dense white sea', the fog renders the topography of the moor increasingly illegible. As Holmes admits, it is " "the one thing upon earth which could have disarranged my plans"': "If [Henry] isn't out in a quarter of an hour the path will be covered. In half an hour we won't be able to see our hands in front of us"' (756). Indeed, it is possible that the paralysis that strikes Holmes, Watson and Lestrade as the hound bursts through the fog is attributable not simply to the affective potency of the creature but, in addition, to the breakdown of the epistemological frameworks by which they read and interpret the world around them.

Although Holmes (just) manages to save Sir Henry as he emerges out of the fog into the 'clear, starlit night' (756), the concept of legibility is not so easily restored. If a 'panoptic view', as Pittard suggests in the passage cited above, renders everything 'visible and immediately comprehensible', the unquantifiable depths of the moor frustrate epistemological certainty. As Mortimer suggests in the early chapters of the novel, there 'is a realm in which the most acute and most experienced of detectives is helpless' (680) and it is significant that once Holmes descends from the heights of the tor onto the moor itself, his power is called into question. Searching for any trace of Stapleton, Watson and Holmes are defeated by the 
unstable topography of the bog and their sense of agency is dwarfed by the power of the landscape:

a false step plunged us more than once thigh-deep into the dark, quivering mire, which shook for yards in soft undulations around our feet. Its tenacious grip plucked at our heels as we walked, and when we sank into it it was as if some malignant hand was tugging us down into those obscene depths, so grim and purposeful was the clutch in which it held us ... There was no chance of finding footsteps in the mire, for the rising mud oozed swiftly in upon them. (760)

Stapleton, along with the possibility of 'certainty and conclusion', is lost forever.

\section{The Man on the Tor}

As suggested above, Watson sees Holmes, much like Selden and Stapleton, as closely associated with the moor. The detective appears just as the escaped convict disappears from sight and the metonymic association effectively establishes them as doubles. This perception is reinforced by the fact that both hide amongst the ancient huts scattered across the moor; indeed Holmes describes Selden as his "“neighbour”" (745). Holmes also shares a number of characteristics with Stapleton. As is often pointed out by critics, both men are characterised by 'hidden fires' $(713,745)$ while their areas of respective expertise - deduction and entomology - are associated with the nets used to capture their prey $(706,750)$. The doubling of Holmes and a criminal antagonist is not unusual in the canon - we see it most obviously in his pairing with Moriarty. Here, it is central to the novel's questioning of the various binaries upon which it depends: science/supernatural, rational/irrational, civilised/savage. More generally, such doubling can be read as an acknowledgement that 'the figure of the detective, in the act of social cleansing, could also be dangerously impure, as the mediator between 
respectable society ... and the criminal'. ${ }^{23}$ What is less certain, however, is whether Holmes, like his doubles, has a close association with the moor.

Watson recounts the first sighting of Holmes as follows:

There, outlined as black as an ebony statue on that shining background, I saw the figure of a man upon the tor ... [T] he figure was that of a tall, thin man. He stood with his legs a little separated, his arms folded, his head bowed, as if he were brooding over that enormous wilderness of peat and granite which lay before him. He might have been the very spirit of that terrible place. (726)

Without doubt, there is something spectral about this scene. It is as if the 'spirit' that Holmes sent to hover over Devonshire in the third chapter has taken on an embodied form. Nor is it insignificant that Watson, waiting within Holmes's hiding place, 'quivered at the vagueness and the terror of [the] interview' (739), thus aligning the detective with the formlessness of the moor. When, however, we separate ourselves from Watson's perspective, it is clear that this 'spirit' is much more closely aligned with the solid and stable topography of London than the shifting surface of the moor.

Portrayed as a 'statue' upon a 'sharp pinnacle of granite' (726), Holmes is associated with fixity rather than flux. Scrutinising his appearance, Watson notes that:

He was thin and worn, but clear and alert, his keen face bronzed by the sun and roughened by the wind. In his tweed suit and cloth cap he looked like any other tourist upon the moor, and he had contrived, with that catlike love of personal cleanliness which was one of his characteristics, that his chin should be as smooth and his linen as perfect as if he were in Baker Street. (740)

When Holmes's immaculate appearance is put together with his location on the granite and statuesque bearing (which is repeated in the portrait reading scene where he is described as 'a 
clear-cut classical statue' (749)), they suggest how impervious he is to the affective power of the moor. Unlike Watson and Sir Henry, Holmes remains unaffected by his surroundings. The pointed reference to his status as a tourist, moreover, confirms that he does not belong there. The detective's immunity to the moor is, furthermore, paired with a conscious or unconscious denial of its power to destabilise meaning. How else might one explain, in the face of Stapleton's disappearance, his falsely confident assertion to Watson that, "II do not know that this place contains any secret which we have not already fathomed"' (760) - an especially inappropriate claim given the moor's resistance to precise measurement - and, back in London, that "II am not aware that there is anything which has remained a secret to us"' (760-1). Nor is it irrelevant that the final retrospective chapter contains a number of references to repression. As Watson informs the reader, Holmes's 'clear and logical mind would not be drawn from its present work to dwell upon memories of the past' and, as the detective himself admits, "I cannot guarantee that I carry all the facts in my mind. Intense mental concentration has a curious way of blotting out what has happened"” (761). Only by "blotting out" the destabilisation associated with the moor is Holmes able to restore the ideal of legibility established in the early chapters.

Many critics have commented upon the extent to which The Hound of the Baskervilles challenges the popular construction of Holmes as the personification of rational positivism. As this chapter has demonstrated, this challenge is clearly linked to the novel's competing topographies, captured most clearly in the flat and legible surface of the ordnance map and the reality of the ever-shifting Grimpen Mire. It is, in conclusion, worth noting the role played by the topography of the narrative itself in exploring this challenge. If, as is largely agreed, the Gothic elements are never adequately contained, structurally or otherwise, surely this is because the linear and connected narrative offered by Holmes in the final retrospective chapter falls flat; like the map itself, it fails to capture the jagged heights and treacherous 
lows of their adventure on the moors. Here, even more than usual, it is the quality of Watson's writing most despised by Holmes - the "“fatal habit of looking at everything from the point of view of a story instead of as a scientific exercise"' (ABBE 636) - that keeps the reader in its 'tenacious grip'.

\section{A Final Word}

As suggested in the opening paragraph of this chapter, the rationale for 'slaying Holmes' stemmed from Doyle's belief that he 'takes my mind from better things'. As he explained in his autobiography: 'All things find their level, but I believe that if I had never touched Holmes, who has tended to obscure my higher work, my position in literature would at the present moment be a more commanding one' (Memories 81 ). This position, Doyle believed, was to be achieved though his carefully researched historical fiction, novels such as The White Company (1891) and Sir Nigel (1906). Such work, he believed, was on 'a larger and more ambitious scale' than the Holmes stories, which he 'regarded as a lower stratum of literary achievement' (Memories 215, 99). Indeed, when asked to write a preface for a new edition of A Study in Scarlet he refused, declaring that 'so elementary a form of fiction as the detective story hardly deserves the dignity of a Preface' ${ }^{24}$ Given the lexicon employed to describe his attitude towards different types of literary production, it is easy to read Doyle's career in terms of an evolutionary journey in which he made a conscious effort to progress from a lower and more elementary form of writing to that of a more ambitious, complex and higher nature. Like the moors of Dartmoor, the reading public can be seen to consist of both 'men of education' and 'peasants' $(678,706)$, those 'who are not content with a mere fiend dog but must needs describe him with hell-fire shooting from his mouth and eyes' (727). It is the latter who clamour for the Holmes stories while the former represent Doyle's ideal audience, those who are able to appreciate his historical writing. Although it is seldom 
remarked upon, it is significant that the narrative of the Baskerville family curse is interrupted by a parenthetical plea from a father to his sons - from Doyle to his readers - to turn from sensational legend to history proper as Hugo Baskerville 'most earnestly commend[s]' Edward Hyde's The History of the Rebellion (1702-4) - the authoritative history of the English Civil War - to the readers' attention (674). Set within this context, The Hound of the Baskervilles can be seen as a form of literary regression, an atavistic throwback to an earlier, more primitive period of Doyle's own development. In the penultimate chapter of the novel, Watson describes how the 'tenacious grip' of the mire 'plucked at our heels ... as if some malignant hand was tugging us down into those obscene depths, so firm and purposeful was the clutch in which it held us' (760). Doyle may well have felt the same way about Holmes: the great creation from which he was never able to free himself.

${ }^{1}$ Jon Lellenberg et al., (eds.), Arthur Conan Doyle: A Life in Letters (London: Harper Perennial, 2008), 300.

${ }^{2}$ Ibid., 319.

${ }^{3}$ Ibid., 477.

${ }^{4}$ Maurizio Ascari, A Counter-History of Crime Fiction: Supernatural, Gothic, Sensational (Basingstoke: Palgrave Macmillain, 2007), 1.

5 Sigmund Freud, 'The "Uncanny", in Art and Literature, trans. James Strachey. The Penguin Freud Library, vol. 14 (London: Penguin, 1990), 335-76 (371, 375).

${ }^{6}$ Nicholas Royle, The Uncanny (Manchester University Press, 2003), 1. Emphasis added.

${ }^{7}$ Srdjan Smajić, Ghost-Seers, Detectives and Spiritualists: Theories of Vision in Victorian Literature and Science (Cambridge University Press, 2010), 71.

${ }^{8}$ Ibid., 71-72. 
${ }^{9}$ Victoria Margree and Bryony Randall, 'Fin-de-Siècle Gothic', in Andrew Smith and William Hughes (eds.), The Victorian Gothic (Edinburgh University Press, 2012), 217-233 (231).

${ }^{10}$ Christopher Pittard, Purity and Contamination in Late Victorian Detective Fiction (Farnham: Ashgate, 2011), 73.

${ }^{11}$ Lynda Nead, Victorian Babylon: People, Streets and Images in Nineteenth-Century London (New Haven and London: Yale University Press, 2000), 74-5.

${ }^{12}$ Shelley Trower, 'On the Cliff Edge of England: Tourism and the Imperial Gothic in Cornwall', Victorian Literature and Culture 40 (2012), 199-214 (200).

${ }^{13}$ Tyler Roeger, 'The Ocean and the Urban: Poe's "The Oblong Box"', Atlantic Studies 13:2 (2016), 227-48 (228).

${ }^{14}$ Kelly Hurley, The Gothic Body: Sexuality, Materialism, and Degeneration at the Fin de Siècle (Cambridge University Press, 1996), 16.

${ }^{15}$ Catherine Belsey, Critical Practice, 1980, $2^{\text {nd }}$ ed. (London and New York: Routledge, 2002), 91-92.

${ }^{16}$ Nils Clausson, 'Degeneration, Fin-de-Siècle Gothic, and the Science of Detection: Arthur Conan Doyle's The Hound of the Baskervilles and the Emergence of the Modern Detective Story', Journal of Narrative Theory 35:1 (2005), 60-87 (72).

${ }^{17}$ Ibid., 71.

${ }^{18}$ Quoted in Ronald R. Thomas, Detective Fiction and the Rise of Forensic Science (Cambridge University Press, 1999), 122.

${ }^{19}$ Quoted in Merlin Coverley, Psychogeography (Harpenden: Pocket Essentials, 2010), 9.

${ }^{20}$ Roeger, 'The Ocean', 228.

${ }^{21}$ Ibid., 235.

${ }^{22}$ Ibid., 242, 228. 
${ }^{23}$ Pittard, Purity, 93.

${ }^{24}$ Quoted in Daniel Stashower, Teller of Tales: The Life of Arthur Conan Doyle (New York: Henry Holt and Company, 1999), 84. 